DOI: $10.19195 / 0524-4544.326 .5$

HENRYK NOWICKI

ORCID: 0000-0003-0392-2433

Uniwersytet Mikołaja Kopernika

\title{
Ochotnicza straż pożarna jednostką ochrony przeciwpożarowej
}

\section{Początki kształtowania się struktur i zadań ochotniczych straży pożarnych w systemie prawa polskiego}

Za podstawowy ,wyznacznik regulacji prawa administracyjnego materialnego należy uznać potrzeby ludzi”1, które obejmują między innymi ochronę przeciwpożarową. Prawodawca wskazuje, że ochrona przeciwpożarowa polega na realizacji przedsięwzięć mających na celu ochronę życia, zdrowia, mienia lub środowiska przed pożarem, klęską żywiołową lub innym miejscowym zagrożeniem $^{2}$. Przy tym ochrona ta, jak stanowi ustawodawca, polega na zapobieganiu powstawania lub rozprzestrzeniania się tych zagrożeń, zapewnieniu sił i środków do ich zwalczania oraz prowadzeniu akcji ratowniczych w przypadku powstania określonego zagrożenia. Ochrona przed zagrożeniami, w tym ochrona przeciwpożarowa, jest dziś jednym z ważniejszych zadań publicznych organów władzy, ze szczególnym wskazaniem organów administracji publicznej, wraz z zorganizowanym systemem wyspecjalizowanych podmiotów realizujących owe zadania.

${ }^{1}$ Z. Duniewska, Zakres regulacji prawa administracyjnego materialnego - wyznaczenie pojęcia instytucji tego prawa, [w:] System Prawa Administracyjnego, t. 7. Prawo administracyjne materialne, red. R. Hauser, Z. Niewiadomski, A. Wróbel, Warszawa 2012, s. 148.

${ }^{2}$ Art. 1 ustawy z dnia 24 sierpnia 1991 roku o ochronie przeciwpożarowej (tekst jedn. Dz.U. z 2018 r. poz. 620). 
Już w okresie międzywojennym wprowadzono przepisy regulujące system ochrony przed pożarami oraz innymi klęskami ${ }^{3}$. Gminy miały zapewnić funkcjonowanie dostatecznej liczby jednostek straży pożarnej zdolnych do wykonywania wyznaczonych zadań. Realizację tego celu z kolei powierzono organom wykonawczym gmin działającym jako organy wykonawcze rządowej administracji ogólnej. System organizacyjny wskazywał, że straże pożarne mogły mieć charakter ochotniczy, przymusowy, zawodowy lub prywatny. Obowiązek utworzenia straży pożarnej zawodowej dotyczył gmin, w których liczba mieszkańców przekraczała 40 tys. Powołanie straży przymusowej następowało, gdy nie powołano ochotniczych straży pożarnych lub gdy ich liczba była niewystarczająca do zapewnienia niezwłocznej realizacji akcji ratunkowych. Natomiast strażami prywatnymi były straże pożarne, których tworzenie i utrzymywanie należało do obowiązków dużych przedsiębiorstw, zakładów oraz instytucji. Obowiązek powoływania tego rodzaju straży dotyczył również przedsiębiorstw oraz innych podmiotów, które ze względu na charakter swojej działalności w dużym stopniu były narażone na niebezpieczeństwo pożaru. W gminach możliwe było powoływanie związku ${ }^{4}$ straży pożarnych o charakterze wyższej użyteczności, co skutkowało obowiązkiem przynależności do tego związku ochotniczych straży pożarnych z terenu danej gminy. Gminom przyznano uprawnienie do tworzenia wspólnie z innymi gminami okręgowego pogotowia pożarowego, które mogło mieć charakter ochotniczy lub zawodowy. Organami administracji publicznej właściwymi w sprawach ochrony przed pożarami i innymi klęskami były organy wykonawcze gmin, wydziały powiatowe, wojewodowie oraz minister spraw wewnętrznych. Sprawy majątkowe zostały przesądzone w ustawie, w której wskazano gminę jako właściciela mienia służącego strażom pożarnym, przy jednoczesnym zobowiązaniu do jego zakupu z budżetu gminnego. W przypadku okręgowego pogotowia pożarnego właścicielem mienia był powiat ${ }^{5}$.

Do obowiązków straży pożarnych należało niezwłoczne udzielanie pomocy i ratunku na obszarze ich działania w razie pożaru lub innych klęsk, jak również w akcji obrony przeciwlotniczej i przeciwgazowej, w innych zaś przypadkach na polecenie władzy lub gdy była potrzebna pomoc przy użyciu sprzętu ratowniczego i stworzenie na miejscu działania odpowiedniej organizacji przeznaczonej do takich celów ${ }^{6}$. Straże pożarne w zakresie realizowanych zadań zostały wypo-

${ }^{3}$ Art. 1 ustawy z dnia 13 marca 1934 roku o ochronie przed pożarami i innemi klęskami (Dz.U. RP. Nr 41, poz. 365).

${ }^{4}$ Do związków i stowarzyszeń członków straży pożarnych stosowało się przepisy rozporządzenia Prezydenta Rzeczypospolitej z dnia 27 października 1932 roku Prawo o stowarzyszeniach (Dz.U. RP. Nr 94, poz. 808).

${ }^{5}$ Szerzej na temat historii straży pożarnych funkcjonujących na terytorium Pomorza Nadwiślanego zob. S. Giziński, Pożarnictwo Pomorza Nadwiślanego od XIX wieku do 1939 roku, Włocławek 2003.

${ }^{6}$ Art. 19 ust. 1 ustawy z 1934 roku. 
sażone w prawo korzystania z wszystkich rodzajów dróg i gruntów prywatnych, a ich pojazdy zostały uprzywilejowane w ruch drogowym; straż zyskała też prawo zajęcia i korzystania ze środków komunikacji publicznych i prywatnych. Członkowie straży pożarnych zostali objęci ochroną prawną przysługującą urzędnikom, wprowadzono także wobec nich obowiązek ubezpieczenia. Koszty ewentualnych roszczeń i odszkodowań związanych z prowadzonymi akcjami ratunkowymi były pokrywane przez zakłady ubezpieczeniowe lub - w przypadku braku ubezpieczeń — przez gminy.

\section{Zadania i sytuacja prawna OSP $\mathrm{w}$ prawodawstwie Polski Ludowej}

Kolejnym aktem prawnym dotyczącym organizacji ochrony przeciwpożarowej była ustawa z 1950 roku $^{7}$, która wyodrębniała straże zawodowe oraz ochotnicze terenowe działające jako stowarzyszenia. Na nowo zorganizowano system organów administracji publicznej i innych podmiotów właściwych w sprawach ochrony przeciwpożarowej. Powołano Komendę Główną Straży Pożarnych, a także wojewódzkie i powiatowe komendy straży pożarnych, określając, że należą do nich kierownictwo i nadzór nad całokształtem ochrony przeciwpożarowej. Do podstawowych zadań komend straży pożarnych prawodawca zaliczył: organizację straży pożarnych i okręgowych pogotowi pożarniczych oraz nadzór nad ich ustrojem i działalnością; szkolenie fachowe w zakresie akcji zapobiegawczej i walki z pożarami; planowanie potrzeb technicznych straży pożarnych dotyczących sprzętu, ekwipunku, narzędzi i taboru; popieranie wynalazków i wytwórczości przeciwpożarowej tudzież wniosków dotyczących normalizacji w zakresie ochrony przeciwpożarowej; współdziałanie z władzami państwowymi i samorządowymi, związkami zawodowymi oraz organizacjami społecznymi w zakresie: obrony przeciwlotniczej, walki z powodzią i innymi klęskami, ratownictwa i pomocy sanitarnej, wychowania fizycznego, przysposobienia wojskowego i zawodowego oraz pracy kulturalno-oświatowej.

Przepisy z 1950 roku zostały zastąpione w 1960 roku nową ustawą ${ }^{8}$, której przepisy nałożyły obowiązek zapobiegania pożarom i ich zwalczania na wszystkie organy administracji państwowej, jednostki gospodarki uspołecznionej, instytucje oraz organizacje społeczne i zawodowe, a także osoby fizyczne i prawne. Utrzymano dotychczasowy podział straży, które zostały powołane do bezpośred-

${ }^{7}$ Ustawa z dnia 4 lutego 1950 roku o obronie przeciwpożarowej i jej organizacji (tekst pierwotny Dz.U. Nr 6, poz. 51).

${ }^{8}$ Ustawa z dnia 13 kwietnia 1960 roku o ochronie przeciwpożarowej (Dz.U. Nr 20, poz. 120 ze zm.). 
niego wykonywania zadań ochrony przeciwpożarowej. W pierwszej kolejności za dbanie o stan bezpieczeństwa pożarowego odpowiadały rady narodowe, które powoływały i nadzorowały straże zawodowe i obowiązkowe oraz współdziałały w organizowaniu ochotniczych straży pożarnych, wspierając ich działalność. Jednocześnie rady narodowe zobowiązano do zapewnienia strażom pożarnym: środków alarmowania i łączności, pomieszczeń, wyekwipowania, sprzętu i urządzeń przeciwpożarowych oraz środków transportowych do akcji ratowniczych i do przeprowadzania ćwiczeń. Do podstawowych zadań straży pożarnych przepisy ustawy zaliczały: prowadzenie przeciwpożarowej działalności zapobiegawczej; prowadzenie akcji ratowniczej w czasie pożarów oraz innych klęsk żywiołowych i katastrof; współudział w terenowej obronie przeciwlotniczej oraz wykonywanie innych czynności związanych z ochroną przeciwpożarową (art. 8). Dodatkowo ustawa określała zadania ochotniczych straży pożarnych, które wspólnie z mieszkańcami miast i wsi oraz z załogami zakładów pracy były zobowiązane do podejmowania zadań w zakresie ochrony przeciwpożarowej i współdziałania z radami narodowymi i innymi organami państwowymi w powszechnej działalności zwalczania pożarów i innych klęsk żywiołowych (art. 9). Jednocześnie wszystkim członkom straży pożarnych zapewniano taką ochronę jak pracownikom państwowym. Utrzymano również strukturę organizacyjną właściwych organów powołanych do wykonywania zadań związanych z ochroną przeciwpożarową, zobowiązując ministra spraw wewnętrznych do współdziałania w zakresie wykonywanych zadań ze Związkiem Ochotniczych Straży Pożarnych.

Przepisami ustawy z 1975 roku $^{9}$ nieco zmieniono zakres pojęcia ochrony przeciwpożarowej, utrzymując krąg podmiotów zobowiązanych do realizacji obowiązków w tym zakresie ${ }^{10}$. Zmodyfikowano również strukturę organów właściwych w sprawach ochrony przeciwpożarowej do nowej organizacji administracji terenowej ${ }^{11}$. Jednocześnie w stosunku do członków ochotniczych oraz obowiązkowych straży pożarnych w czasie wykonywania czynności wynikających z przepisów o ochronie przeciwpożarowej utrzymano ochronę prawną na równi z ochroną przysługującą funkcjonariuszom publicznym. Ochotniczym stra-

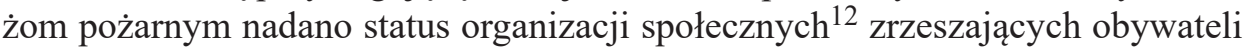
polskich, gotowych czynnie i w zorganizowany sposób uczestniczyć w ochronie życia, zdrowia i mienia obywateli oraz majątku narodowego przed pożarami ${ }^{13}$.

${ }^{9}$ Ustawa z dnia 12 czerwca 1975 roku o ochronie przeciwpożarowej (Dz.U. Nr 20, poz. 106 ze zm.).

10 „Art. 1: Ochrona życia i zdrowia ludzkiego oraz dorobku materialnego i kulturalnego społeczeństwa przed pożarami jest obowiązkiem wszystkich organów władzy i administracji państwowej, instytucji państwowych, jednostek gospodarki uspołecznionej, organizacji społecznych oraz każdego obywatela”.

${ }^{11} \mathrm{~W}$ związku z likwidacją powiatów powołano rejonowych komendantów straży pożarnych.

12 Zob. E. Smoktunowicz, Prawo obywateli do organizowania się, [w:] System Prawa Administracyjnego, t. 4, red. T. Rabska, Wrocław 1980, s. 48.

${ }^{13}$ Art. 30 ust. 1 ustawy z 1975 roku. 
Ustawodawca przesądził o charakterze prawnym terenowych ochotniczych straży pożarnych, przyznając im osobowość prawną, którą uzyskiwały po zarejestrowaniu przez wójta lub burmistrza. Prowadzenie rejestru terenowych ochotniczych oraz zakładowych straży pożarnych zostało określone jako zadanie zlecone gminie. Utrzymano zrzeszanie się ochotniczych straży pożarnych w Związku Ochotniczych Straży Pożarnych (dalej: ZOSP) ${ }^{14}$, który będąc organizacją społeczną posiadającą osobowość prawną, odpowiadał za działalność na rzecz ochrony przeciwpożarowej. Wśród szczegółowych zadań ZOSP prawodawca wskazał między innymi: pobudzanie i wszechstronne rozwijanie wszelkiej inicjatywy zmierzającej do zwiększenia udziału społeczeństwa w ochronie przeciwpożarowej; prowadzenie pracy społeczno-wychowawczej oraz pogłębianie uczuć patriotyzmu członków ochotniczych straży pożarnych, a także ustalanie wytycznych dla ochotniczych straży pożarnych w zakresie zadań społeczno-wychowawczych ${ }^{15}$. Ważnym uprawnieniem przyznanym członkom ochotniczych straży pożarnych była możliwość nakładania przez nich mandatu karnego za wykroczenia z zakresu ochrony przeciwpożarowej poddane orzecznictwu kolegiów do spraw wykroczeń ${ }^{16}$. Tym samym zostali oni włączeni do szeroko rozumianego aparatu administracji państwowej mogącego stosować sankcje administracyjne ${ }^{17}$.

\section{Ochotnicze straże pożarne we współczesnym prawie polskim}

Nowemu określeniu zadań w zakresie ochrony przeciwpożarowej oraz dostosowaniu rozwiązań prawnych do zmieniającej się rzeczywistości ustrojowej służyła ustawa z 1991 roku $^{18}$. Ważna i zarazem powiązana $\mathrm{z}$ badanym tematem była regulacja dotycząca Państwowej Straży Pożarnej (dalej: PSP) ${ }^{19}$. W obu ustawach zapowiedziano utworzenie systemu ratowniczo-gaśniczego. Definiu-

${ }^{14}$ Związek został reaktywowany w 1956 roku w miejsce przedwojennego Głównego Związku Straży Pożarnych Rzeczypospolitej Polskiej, utworzonego w 1921, a rozwiązanego w 1949 roku na mocy rozporządzenia Rady Ministrów, http://www.zosprp.pl/?q=content/historia-zwiazku-osp-rp-0 (dostęp: 6.11.2018).

15 Art. 35 ustawy z 1975 roku.

16 Art. 33 ust. 1 ustawy z 1975 roku.

${ }^{17}$ Szerzej na temat sankcji administracyjnych zob. H. Nowicki, Sankcje administracyjne, [w:] System Prawa Administracyjnego, t. 7. Prawo administracyjne materialne, red. R. Hauser, Z. Niewiadomski, A. Wróbel, Warszawa 2017, s. 649.

18 Ustawa z dnia 24 sierpnia 1991 roku o ochronie przeciwpożarowej (tekst pierwotny Dz.U. $\mathrm{Nr} 81$, poz. 351).

${ }^{19}$ Ustawa z dnia 24 sierpnia 1991 roku o Państwowej Straży Pożarnej (tekst pierwotny Dz.U. Nr 88, poz. 400). 
jąc pojęcie ochrony przeciwpożarowej ${ }^{20}$, prawodawca wskazał, że polega ona na realizacji przedsięwzięć mających na celu ochronę życia, zdrowia, mienia lub środowiska przed pożarem, klęską żywiołową lub innym miejscowym zagrożeniem poprzez: zapobieganie powstawaniu i rozprzestrzenianiu się pożaru, klęski żywiołowej lub innego miejscowego zagrożenia; zapewnienie sił i środków do zwalczania pożaru, klęski żywiołowej lub innego miejscowego zagrożenia oraz prowadzenie działań ratowniczych ${ }^{21}$.

Prawodawca uznał Komendanta Głównego PSP za centralny organ administracji państwowej właściwy w sprawach ochrony przeciwpożarowej oraz organizacji krajowego systemu ratowniczo-gaśniczego (dalej: KSRG) ${ }^{22}$. W 1998 roku zdefiniowano ${ }^{23}$ pojęcie systemu ratowniczo-gaśniczego, poszerzając zakres zadań wykonywanych również przez OSP, będące częścią tego systemu. KSRG został ujęty w przepisach ustawy jako integralna część organizacji bezpieczeństwa wewnętrznego państwa obejmująca działania podejmowane w celu ratowania życia, zdrowia, mienia lub środowiska, polegające na prognozowaniu, rozpoznawaniu i zwalczaniu pożarów, klęsk żywiołowych lub innych miejscowych zagrożeń. W ramach tego systemu działają jednostki ochrony przeciwpożarowej, inne służby, inspekcje, straże, instytucje oraz podmioty, które dobrowolnie w drodze umowy cywilnoprawnej zgadzają się współdziałać w akcjach ratowniczych ${ }^{24}$. Jednocześnie wskazano, że częścią systemu ochrony przeciwpożarowej są ochotnicze straże pożarne, które uczestniczą bezpośrednio w działaniach ratowniczych, oraz ZOSP ${ }^{25}$. Tak szerokie ujęcie podmiotów uczestniczących w KSRG skutkuje obowiązkiem współdziałania OSP z wszystkimi jednostkami tego systemu oraz innymi, znajdującymi się poza $\operatorname{nim}^{26}$. W przypadku OSP mamy do czynienia z przekazaniem zadań publicznych (zadań państwa) w drodze ustawy podmiotom prywatnym, przy czym udział tych podmiotów w wykonywaniu przekazanych

20 J. Jagielski i M. Cherka określają ten obszar regulacji jako ,państwową służbę administracyjną w zakresie ochrony przeciwpożarowej”, zob. eidem, Regulacje ochrony przeciwpożarowej, [w:] Prawo administracyjne, red. M. Wierzbowski, Warszawa 2017, s. 671.

${ }^{21}$ Z. Leoński zaliczał zadania związane z zagrożeniami wewnętrznymi, takimi jak klęski żywiołowe, powodzie i pożary, do funkcji policyjnych państwa (policja administracyjna), zob. idem, Materialne prawo administracyjne, Warszawa 2005, s. 19 oraz $207 \mathrm{n}$.

22 Art. 14 ust. 1 ustawy z 24 sierpnia 1991 roku.

23 Art. 75 ustawy z dnia 24 lipca 1998 roku o zmianie niektórych ustaw określających kompetencje organów administracji publicznej w związku z reformą ustrojową państwa (Dz.U. Nr 106, poz. 668).

${ }^{24}$ Art. 2 pkt 4 ustawy z 24 sierpnia 1991 roku.

25 Art. 15 ustawy z 24 sierpnia 1991 roku.

26 Jednostki KSRG współpracują między innymi z policją, strażami miejskimi, Strażą Graniczną, Państwowym Ratownictwem Medycznym, Stacjami Ratownictwa Górniczego, Morską Służbą Poszukiwawczą, Państwową Inspekcją Ochrony Środowiska oraz z wieloma organizacjami pozarządowymi. 
zadań publicznych odbywa się na podstawie przepisów ustrojowych oraz kompetencyjnych, które są zawarte w powoływanych aktach prawnych ${ }^{27}$.

Prawodawca przesądził, że zarówno OSP, jak i ZOSP mają działać na podstawie przepisów ustawy o stowarzyszeniach. Niezależnie od statusu prawnego OSP jako stowarzyszenia został utrzymany obowiązek uczestniczenia w systemie ochrony przeciwpożarowej i poddania tych jednostek działaniom władczym PSP, która mogła wzywać te jednostki do działań ratowniczych poza terenem swojego działania. Prawodawca określił OSP jako jednostki umundurowane, które są wyposażone we właściwy sprzęt przeznaczony w szczególności do walki z pożarami, klęskami żywiołowymi lub innymi miejscowymi zagrożeniami ${ }^{28}$.

Podstawowym aktem powołania i funkcjonowania stowarzyszenia jest jego statut $^{29}$, który w przypadku OSP i zadań dotyczących ochrony przeciwpożarowej wymaga uzgodnienia $z$ właściwymi organami PSP. Tym samym ze względu na zakres realizowanych przez OSP zadań publicznych samodzielność tak zwana statutowa jest ograniczona prawnie. Uczestnictwo OSP w systemie ratowniczo-gaśniczym oraz w systemie ochrony przeciwpożarowej jednoznacznie wskazuje na ustawowe przekazanie zadań publicznych podmiotom prywatnym. W związku z realizowanymi zadaniami publicznymi minister właściwy do spraw wewnętrznych w porozumieniu z Ministrem Obrony Narodowej ma prawo określić formy współdziałania OSP z Wojskami Obrony Terytorialnej ${ }^{30}$. To współdziałanie może dotyczyć takich spraw, jak wymiana informacji na temat współdziałania oraz formy koordynacji wspólnych przedsięwzięć służących sprawnej współpracy.

Należy również wskazać, że powierzone zadania należą do najważniejszych zadań publicznych — zapewnienia bezpieczeństwa wewnętrznego państwa ${ }^{31}$. Jest ono określone przepisami Konstytucji, a za jego realizację odpowiedzialna jest Rada Ministrów ${ }^{32}$. Takie umiejscowienie polityki bezpieczeństwa wewnętrznego państwa, obejmującej ochronę przeciwpożarową i KSRG, wskazuje na istotę i rangę zadań realizowanych w ramach tych systemów przez OSP. Konsekwencją jest objęcie funkcjonujących jednostek przynależnych do tych systemów, niezależnie od ich charakteru prawnego (czy są to jednostki publiczne, czy prywatne), finansowaniem $z$ budżetu państwa oraz ochroną prawną osób wykonujących określone czynności w związku z realizowanymi zadaniami. Ważnym zagadnieniem jest zróżnicowanie OSP ze względu na przynależność części tych jednostek do

27 Zob. M. Stahl, Określenia jednostek organizacyjnych wykonujacych zadania administracji publicznej, ich zróżnicowanie i uwarunkowania, [w:] System Prawa Administracyjnego, t. 6. Podmioty administrujące, red. R. Hauser, Z. Niewiadomski, A. Wróbel, Warszawa 2011, s. 49.

28 Art. 19 ust. 1a ustawy z 24 sierpnia 1991 roku.

29 Art. 9 i 10 ustawy z dnia 7 kwietnia 1989 roku — Prawo o stowarzyszeniach (tekst jedn. Dz.U. z 2017 r. poz. 210).

${ }^{30}$ Art. 19 ust. 1c i 1 d ustawy z 24 sierpnia 1991 roku.

31 Art. 2 pkt 4 ustawy z 24 sierpnia 1991 roku.

32 Art. 146 ust. 4 pkt 7 Konstytucji RP z dnia 2 kwietnia 1997 roku (Dz.U. Nr 78, poz. 483 ze zm.). 
KSRG. Fakt przynależności OSP do wspomnianego systemu lub jej brak ${ }^{33}$ nie powinien wpływać na sytuację prawną i finansową tych jednostek. Zadania realizowane przez OSP w ramach KSRG lub poza tym systemem są zawsze zadaniami publicznymi skierowanymi do określonych społeczności lokalnych lub szerzej — do społeczności regionalnych. Zawsze są to również zadania, które należy zaliczyć do sfery bezpieczeństwa wewnętrznego państwa, dlatego wszystkie OSP powinny być jednakowo traktowane przez właściwe organy państwa. Samą OSP zatem trzeba uznać za organizację pozarządową ${ }^{34}$ typu non profit, niezależnie od możliwości podjęcia dodatkowej działalności gospodarczej, która jednak będzie służyła realizacji zadań statutowych. Rozumiejąc problematykę działań OSP w ramach polityki bezpieczeństwa wewnętrznego, prawodawca nałożył zadania z tym związane również na samorządy terytorialne. Wśród zadań własnych gminy związanych z zaspokajaniem potrzeb wspólnoty wyodrębnia się między innymi sprawy ochrony środowiska i przyrody oraz gospodarki wodnej, porządku publicznego i bezpieczeństwa obywateli oraz ochrony przeciwpożarowej i przeciwpowodziowej, w tym wyposażenia i utrzymania gminnego magazynu przeciwpowodziowego ${ }^{35}$. Gminy zostały również zobowiązane do współpracy i działalności na rzecz organizacji pozarządowych i podmiotów wskazanych w przepisach ustawy o działalności pożytku publicznego i wolontariacie jako prowadzące działalność pożytku publicznego ${ }^{36}$. Nowelizacją z 2018 roku ustawy o samorządzie gminnym ${ }^{37}$ gminy upoważniono - jeżeli uznają to za konieczne - do stosowania monitoringu na wybranych obszarach przestrzeni publicznej w celu zapewnienia porządku publicznego i bezpieczeństwa obywateli oraz ochrony przeciwpożarowej i przeciwpowodziowej. Podobnie zostały ukształtowane zadania samorządu powiatowego ${ }^{38} \mathrm{w}$ zakresie ochrony przeciwpożarowej i przed innymi zagrożeniami.

Członkom OSP przyznano prawo do otrzymania odszkodowania za uszczerbek na zdrowiu lub szkodę w mieniu doznane w związku z działaniami ratowni-

${ }^{33} \mathrm{Z}$ danych umieszczonych na stronie internetowej ZOSP wynika, że nieco ponad jedna czwarta OSP należy do KSRG, co oznacza, że poza tym systemem znajduje się około trzech czwartych OSP.

34 J. Boć, Organizacje pozarządowe, [w:] Administracja publiczna, red. J. Boć, Wrocław 2003, s. $192 \mathrm{n}$.

35 Art. 7 ustawy z dnia 8 marca 1990 roku o samorządzie gminnym (tekst jedn. Dz.U. z 2018 r. poz. 994 ze zm.).

${ }^{36}$ Art. 3 ust. 3 ustawy z dnia 24 kwietnia 2003 roku o działalności pożytku publicznego i wolontariacie (tekst jedn. Dz.U. z 2018 r. poz. 450 ze zm.).

37 Zob. art. 114 ustawy z dnia 10 maja 2018 roku o ochronie danych osobowych (Dz.U. z 2018 r. poz. 1000).

38 Art. 4 ust. 1 pkt 15, 16 i 22 oraz art. 4b ustawy z dnia 5 czerwca 1998 r. o samorządzie powiatowym (tekst jedn. Dz.U. z 2018 r. poz. 995 ze zm.). Należy mieć na uwadze, że w wypadku miast na prawach powiatu przepisy tej ustawy będą miały również zastosowanie do OSP. 
czymi $^{39}$. Jedną z kolejnych nowelizacji zwiększono zakres uprawnień członków OSP o możliwość otrzymania renty z tytułu całkowitej lub częściowej niezdolności do pracy. Podobne świadczenia zostały przyznane członkom rodzin strażaków z OSP w przypadku ich śmierci. Członków OSP objęto ochroną prawnokarną przysługującą funkcjonariuszom publicznym oraz przyznano im prawo otrzymania ekwiwalentu za udział w działaniach ratowniczych ${ }^{40}$. Główny ciężar utrzymania, wyposażenia oraz zapewnienia gotowości bojowej OSP został nałożony na gminy ${ }^{41}$, łącznie z kosztami umundurowania i ubezpieczenia członków OSP. Część kosztów funkcjonowania OSP, szczególnie tych związanych z działalnością w ramach KSRG, jest pokrywana z budżetu państwa. Równie ważne powinno być zapewnienie członkom OSP niezbędnych szkoleń, których ukończenie jest wymagane do wykonywania określonych czynności w prowadzonych akcjach ratowniczych.

\section{Ochotnicze straże pożarne jako stowarzyszenie i organizacja pożytku publicznego. Wnioski}

Zgodnie z wolą prawodawcy OSP działają jako stowarzyszenia, przy czym należy zwrócić uwagę na fakt istnienia dwóch rodzajów - co do formy prawnej - tych organizacji. Pierwszą kategorią są stowarzyszenia podlegające wpisowi do Krajowego Rejestru Sądowego (dalej: KRS) ${ }^{42}$ i uzyskujące osobowość prawną. Drugim rodzajem są stowarzyszenia zwykłe, będące uproszczoną formą, nieposiadające osobowości prawnej ${ }^{43}$. Ważne dla funkcjonujących OSP są przepisy dotyczące $\mathrm{KRS}^{44}$, do którego z mocy prawa zostały wpisane wszystkie OSP funkcjonujące przed wejściem w życie ustawy o $\mathrm{KRS}^{45}$. W przypadku nowo tworzonych OSP istnieje możliwość wyboru pomiędzy formą stowarzyszenia posiadającego osobowość prawną a stowarzyszenia zwykłego. Te dwa odmienne rodzaje mogą bez jakichkolwiek problemów realizować swe zadania statutowe oraz wynikające $\mathrm{z}$ funkcjonowania w systemie ochrony przeciwpożarowej i KSRG.

Nie dokonując szerszej analizy funkcjonowania OSP jako stowarzyszeń posiadających osobowość prawną, należy zwrócić uwagę na formę stowarzysze-

39 Art. 26 ustawy z 24 sierpnia 1991 roku.

40 Art. 27 ustawy z 24 sierpnia 1991 roku.

41 Art. 32 ustawy z 24 sierpnia 1991 roku.

42 Art. 8 ustawy z dnia 7 kwietnia 1989 roku - Prawo o stowarzyszeniach.

${ }^{43}$ Art. 40 Prawa o stowarzyszeniach.

44 Ustawa z dnia 20 sierpnia 1997 roku o Krajowym Rejestrze Sądowym (tekst jedn. Dz.U. z 2018 r. poz. 986).

${ }^{45}$ Ustawa z dnia 20 sierpnia 1997 roku - Przepisy wprowadzające ustawę o Krajowym Rejestrze Sądowym (Dz.U. Nr 121, poz. 770 ze zm.). 
nia zwykłego. W przypadku tworzenia OSP w formie stowarzyszenia zwykłego powstaje poważny problem odpowiedzialności każdego członka za zobowiązania stowarzyszenia zwykłego bez ograniczeń całym swoim majątkiem solidarnie z pozostałymi członkami oraz ze stowarzyszeniem. Co prawda prawodawca stwierdza, że odpowiedzialność ta powstaje z chwilą, gdy egzekucja z majątku stowarzyszenia zwykłego okaże się bezskuteczna, jednak w dalszych przepisach wskazuje na możliwość wniesienia powództwa przeciwko członkowi stowarzyszenia przed stwierdzeniem bezskuteczności egzekucji z majątku stowarzyszenia ${ }^{46}$. Wskazane przepisy, moim zdaniem, znacznie pogorszą sytuację członków tworzonej OSP działającej w formie stowarzyszenia zwykłego. Dlatego też organy państwa odpowiedzialne za system bezpieczeństwa przeciwpożarowego powinny podjąć działania legislacyjne wskazujące, że jedyną formą prawną funkcjonowania OSP jest stowarzyszenie posiadające osobowość prawną. Należy mieć również świadomość, że OSP ma lub może wystąpić do sądu o nadanie jej statusu organizacji pożytku publicznego. Zakres zadań realizowanych przez OSP w zdecydowanej części pokrywa się z działalnością przypisaną organizacjom pożytku publicznego. Może to być prowadzenie działalności w sferze zadań publicznych, do których prawodawca zalicza między innymi: porządek i bezpieczeństwo publiczne, ratownictwo i ochronę ludności oraz pomoc ofiarom katastrof i klęsk żywiołowych ${ }^{47}$. Jednak w przypadku uzyskania przez OSP statusu organizacji pożytku publicznego znacznie skomplikuje się ich sytuacja prawna w zakresie rozliczeń finansowo-księgowych i podatkowych. Dlatego tak ważne jest zapewnienie tym jednostkom profesjonalnej obsługi prawnej oraz księgowej, do czego powinny być zobowiązane gminy.

\section{Bibliografia}

Boć J., Organizacje pozarzadowe, [w:] Administracja publiczna, red. J. Boć, Wrocław 2003.

Duniewska Z., Zakres regulacji prawa administracyjnego materialnego - wyznaczenie pojęcia instytucji tego prawa, [w:] System Prawa Administracyjnego, t. 7. Prawo administracyjne materialne, red. R. Hauser, Z. Niewiadomski, A. Wróbel, Warszawa 2012.

Giziński S., Pożarnictwo Pomorza Nadwiślanego od XIX wieku do 1939 roku, Włocławek 2003.

Jagielski J., Cherka M., Regulacje ochrony przeciwpożarowej, [w:] Prawo administracyjne, red. M. Wierzbowski, Warszawa 2017.

Leoński Z., Materialne prawo administracyjne, Warszawa 2005.

Nowicki H., Sankcje administracyjne, [w:] System Prawa Administracyjnego, t. 7. Prawo administracyjne materialne, red. R. Hauser, Z. Niewiadomski, A. Wróbel, wyd. 2, Warszawa 2017.

${ }^{46}$ Reguluje to art. 40 ust. 1 b i 1c ustawy - Prawo o stowarzyszeniach dodany ustawą z dnia 25 września 2015 roku o zmianie ustawy - Prawo o stowarzyszeniach oraz niektórych innych ustaw (Dz.U. z 2015 r. poz. 1923).

47 Art. 4 ustawy z dnia 24 kwietnia 2003 roku o działalności pożytku publicznego i wolontariacie (tekst jedn. Dz.U. z 2018 r. poz. 450 ze zm.). 
Smoktunowicz E., Prawo obywateli do organizowania się, [w:] System Prawa Administracyjnego, t. 4, red. T. Rabska, Wrocław 1980.

Stahl M., Określenia jednostek organizacyjnych wykonujących zadania administracji publicznej, ich zróżnicowanie i uwarunkowania, [w:] System Prawa Administracyjnego, t. 6. Podmioty administrujace, red. R. Hauser, Z. Niewiadomski, A. Wróbel, Warszawa 2011.

\title{
Wykaz aktów prawnych
}

Konstytucja Rzeczypospolitej Polskiej z dnia 2 kwietnia 1997 roku (Dz.U. Nr 78, poz. 483 ze zm.). Rozporządzenie Prezydenta Rzeczypospolitej z dnia 27 października 1932 roku Prawo o stowarzyszeniach (Dz.U. RP Nr 94, poz. 808).

Ustawa z dnia 13 marca 1934 roku o ochronie przed pożarami i innemi klęskami (Dz.U. RP Nr 41, poz. 365).

Ustawa z dnia 4 lutego 1950 roku o obronie przeciwpożarowej i jej organizacji (tekst pierwotny Dz.U. Nr 6, poz. 51).

Ustawa z dnia 13 kwietnia 1960 roku o ochronie przeciwpożarowej (Dz.U. Nr 20, poz. 120 ze zm.). Ustawa z dnia 12 czerwca 1975 roku o ochronie przeciwpożarowej (Dz.U. Nr 20, poz. 106 ze zm.).

Ustawa z dnia 7 kwietnia 1989 roku — Prawo o stowarzyszeniach (tekst jedn. Dz.U. z 2017 r. poz. 210).

Ustawa z dnia 8 marca 1990 roku o samorządzie gminnym (tekst jedn. Dz.U. z 2018 r. poz. 994 ze $\mathrm{zm}$.).

Ustawa z dnia 24 sierpnia 1991 roku o ochronie przeciwpożarowej (tekst pierwotny Dz.U. Nr 81, poz. 351).

Ustawa z dnia 24 sierpnia 1991 roku o Państwowej Straży Pożarnej (tekst pierwotny Dz.U. Nr 88, poz. 400).

Ustawa z dnia 20 sierpnia 1997 roku o Krajowym Rejestrze Sądowym (tekst jedn. Dz.U. z 2018 r. poz. 986).

Ustawa z dnia 20 sierpnia 1997 roku — przepisy wprowadzające ustawę o Krajowym Rejestrze Sądowym (Dz.U. Nr 121, poz. 770 ze zm.).

Ustawa z dnia 5 czerwca 1998 roku o samorządzie powiatowym (tekst jedn. Dz.U. z 2018 r. poz. 995 ze zm.).

Ustawa z dnia 24 lipca 1998 roku o zmianie niektórych ustaw określających kompetencje organów administracji publicznej w związku z reformą ustrojową państwa (Dz.U. Nr 106, poz. 668).

Ustawa z dnia 24 kwietnia 2003 roku o działalności pożytku publicznego i wolontariacie (tekst jedn. Dz.U. z 2018 r. poz. 450 ze zm.).

Ustawa z dnia 25 września 2015 roku o zmianie ustawy — Prawo o stowarzyszeniach oraz niektórych innych ustaw (Dz.U. z 2015 r. poz. 1923).

Ustawa z dnia 10 maja 2018 roku o ochronie danych osobowych (Dz.U. z 2018 r. poz. 1000).

\section{Volunteer fire department as a part of fire safety}

\author{
Summary
}

This article presents a legal status of volunteer fire departments and their role in the fire safety system. It pays particular attention to the fact that the activity in the field of fire safety belongs to public task, in this case carried out by social organisations. Taking into account the legal status of 
the volunteer fire departments acting as associations which often have a character of public benefit organisations, the author postulates a clear statutory indication of the legal nature of the volunteer fire departments as associations with legal personality. Therefore it is important to equip the volunteer fire departments with professional legal and fund management which should be provided by the relevant municipalities.

Keywords: volunteer fire department, works, legal status, associations, public benefit organisation. 